\title{
Piotr Szymański*
}

\section{PODEJŚCIA I METODY WYCENY W ŚWIETLE STANDARDÓW WYCENY PRZEDSIĘBIORSTW}

\section{WPROWADZENIE}

Od połowy lat 80 . został zapoczątkowany proces współczesnej standaryzacji wyceny przedsiębiorstw. Impulsem do podjęcia unifikacji procesu wyceny był kryzys na rynku nieruchomości na początku lat 80 . na rynku amerykańskim. Wtedy to wyszło na jaw, że wiele wycen sporządzonych dla potrzeb kredytowych zostało zmanipulowanych (przeszacowane), a zabezpieczenia kredytowe były mocno niedoszacowane. Stąd pojawiły się inicjatywy organizacji zrzeszających rzeczoznawców majątkowych określenia minimalnych wymagań jakie należy spełnić w procesie wyceny, aby wycena miała status rzetelnej. Standaryzacja wycen nieruchomości miała na celu ograniczenie ryzyka powstawania błędnych lub też nierzetelnych wycen, a przez to zmniejszenie ryzyka generowania baniek spekulacyjnych na rynku nieruchomości w przyszłości. Kolejny kryzys nieruchomości na rynku amerykańskim ujawnił konflikty interesów i brak standardów etycznych w sektorze finansowym. Jednocześnie pokazał, że standaryzacja procesu wyceny nieruchomości nie chroni przed tego typu zjawiskami. W połowie lat osiemdziesiątych proces standaryzowania wyceny rozszerzał się na kolejne obszary i objął również wycenę przedsiębiorstw. Obecnie w wielu krajach świata istnieją regulacje wpływające na przebieg procesu wyceny przedsiębiorstw, część z tych regulacji została wprowadzona poprzez ustawodawstwo krajowe lub poprzez organizacje zrzeszające ekspertów z danej dziedziny. Wycena przedsiębiorstw jest prawdopodobnie jednym z najbardziej skomplikowanych obszarów wyceny, gdzie występują problemy o charakterze mikro i makroekonomicznym, czy też zarządczym, gdzie istotną rolę odgrywają zjawiska społeczne i psychologiczne. Wszystkie zjawiska obejmują obszary wiedzy, które intensywnie się zmieniają w ostatnich kilkudziesięciu latach pod

\footnotetext{
* Dr nauk o zarządzaniu, Uniwersytet Ekonomiczny we Wrocławiu.
} 
wpływem nowych odkryć naukowych. Zważywszy na ten interdyscyplinarny charakter wyceny przedsiębiorstw i skalę z tym związanych problemów, standaryzacja wyceny przedsiębiorstw powinna być ograniczona do kluczowych elementów procesu wyceny. Jednocześnie standardy powinny podlegać ciągłej rewizji i korektom, które byłyby odpowiedzią na zjawiska zachodzące w przedsiębiorstwie, $w$ gospodarce i nauce.

Niniejszy artykuł ogranicza się tylko do jednego z aspektów poruszanego w standardach wyceny - do obszaru podejść i metod wyceny przedsiębiorstw, który jest dość często poruszany w literaturze z zakresu wyceny przedsiębiorstw. Stąd też celem tego artykułu jest identyfikacja zakresu regulacji oraz różnic między regulacjami w obszarze podejść i metod wyceny w ramach poszczególnych standardów wyceny przedsiębiorstw istniejących w poszczególnych krajach. W związku z tym artykuł próbuje odpowiedzieć na pytanie jak mocno poszczególne standardy wyceny ingerują w metodykę poszczególnych podejść i metod wyceny? Jakie są rozbieżności na tym polu pomiędzy analizowanymi standardami? Dla realizacji tak sformułowanego celu oraz odpowiedzi na postawione pytania przeanalizowano 12 standardów, cztery standardy amerykańskie, standard kanadyjski, australijski, nowozelandzki, chiński (Hong Kong), niemiecki, polski i dwa standardy międzynarodowe. Analizowane standardy obejmują standardy wyceny, którymi posługują się eksperci z zakresu wyceny w kilkudziesięciu krajach świata, stąd też prawdopodobnie obejmują one większość istniejących standardów z tego zakresu, oraz obejmują swym zasięgiem większość ekspertów zakresu wyceny, którzy posługują się standardami wyceny.

\section{ANALIZOWANE STANDARDY WYCENY PRZEDSIĘBIORSTW}

Dla potrzeb analizy porównano następujące standardy ${ }^{1}$ :

- Amerykański - Statement on Standards for Valuation Services z czerwca 2007 r. opracowany przez American Institute of Certified Public Accountants (AICPA), w dalszej części artykułu określany mianem standardów AICPA²,

- Amerykański - Professional Standards z maja 2002 r. opracowany przez National Association of Certified Valuation Analysts (NACVA), w dalszej części artykułu określany mianem standardów NACVA ${ }^{3}$,

\footnotetext{
${ }^{1}$ Badania realizowano w ramach: Projektu badawczego - habilitacyjnego nr N N113 261836, finansowanego przez: Ministerstwo Nauki i Szkolnictwa Wyższego.

${ }^{2}$ Zob. Valuation of a Business, Business Ownership Interest, Security, or Intangible Asset. Statement on Standards for Valuation Services, American Institute of Certified Public Accountants, New York, June 2007.

${ }^{3}$ Zob. Professional Standards, National Association of Certified Valuation Analysts, May 31, 2002.
} 
- Amerykański - ASA Business Valuation Standards z listopada 2009 r. opracowany przez American Society of Appraisers (ASA), w dalszej części artykułu określany mianem standardów $\mathrm{ASA}^{4}$,

- Amerykański - Business Appraisal Standards z października 2001 r. opracowany przez The Institute of Business Appraisers, w dalszej części artykułu określany mianem standardów IBA

- Kanadyjski - Standard No. 110-530 z czerwca 2007 r. opracowany przez The Canadian Institute of Chartered Business Valuators (CICBV), w dalszej części artykułu określany mianem standardu chińskiego ${ }^{6}$,

- Międzynarodowy - International Valuation Standards z lipca 2007 r. opracowany przez International Valuation Standards Council (IVSC), w dalszej części artykułu określany mianem standardów IVSC ${ }^{7}$,

- Międzynarodowy - Professional Standards opracowany przez International Association of Consultants, Valuators, and Analysts (IACVA) 1 czerwca 2011 r., w dalszej części artykułu określany mianem standardów IACVA ${ }^{8}$,

- Nowozelandzki - Independent Business Valuation Engagements z lipca 2003 r. opracowany przez Institute of Chartered Accountants of New Zealand opracowany przy wsparciu The Canadian Institute of Chartered Business Valuators (CICBV), w dalszej części artykułu określany mianem standardów nowozelandzkich ${ }^{9}$,

- Australijski - Valuation Services z lipca 2008 r. opracowany przez Accounting Professional and Ethical Standards Board, w dalszej części artykułu określany mianem standardów australijskich ${ }^{10}$,

- Chiński - Business Valuation Standards z listopada 2005 r. opracowany przez The Hong Kong Business Valuation Forum, w dalszej części artykułu określany mianem standardów chińskich ${ }^{11}$,

- Niemiecki - IDW Standard: Principles for the Performance of Business Valuations (IDW S 1 Version 2008), w dalszej części artykułu określany mianem standardu niemieckiego ${ }^{12}$,

\footnotetext{
${ }^{4}$ Zob. ASA Business Valuation Standards, American Society of Appraisers, 2009.

${ }^{5}$ Zob. Business Appraisal Standards, The Institute of Business Appraisers, 2008.

${ }^{6}$ Standard no 110-530, The Canadian Institute of Chartered Business Valuators, June 2009.

${ }^{7}$ Zob. International Valuation Standards. International Valuation Guidance Note No. 6. Business Valuation, The International Valuation Standards Committee, 2007.

${ }^{8}$ Professional Standards, International Association of Consultants, Valuators, and Analysts (IACVA), June 1, 2011.

${ }^{9}$ Independent Business Valuation Engagements, Advisory Engagement Standard 2, Council of the Institute of Chartered Accountants of New Zealand, 06/2003.

${ }^{10}$ Zob. APES 225 Valuation Services, Accounting Professional and Ethical Standards Board,

${ }^{11}$ Zob. The Hong Kong Business Valuation Forum. Business Valuation Standards, The Hong Kong Business Valuation Forum, November 2005.

${ }^{12}$ IDW Standard: Principles for the Performance of Business Valuations (IDW S 1 Version 2008), IDW Verlag GmbH, Institut der Wirschaftsprüfer in Deutschland, Düsseldorf 2009.
} July 2008. 
- Polski - Nota Interpretacyjna NI 5, Wycena przedsiębiorstw z 2010 r. opracowane przez Polską Federację Stowarzyszeń Rzeczoznawców Majątkowych, w dalszej części artykułu określany mianem standardu polskiego ${ }^{13}$.

\section{PODEJŚCIA I METODY WYCENY W STANDARDACH WYCENY PRZEDSIĘBIORSTW}

Podejścia i metody wyceny są jednym z częściej podejmowanych w literaturze zagadnień w wycenie przedsiębiorstw. Część standardów w przeciwieństwie do podręczników z zakresu wyceny ogranicza się do specyfikacji podejść i metod wyceny nie rozstrzygając $\mathrm{w}$ jakiej sytuacji należy stosować określone podejścia i metody. Stąd też w pierwszej kolejności warto przyjrzeć się jakie podejścia i metody wyceny wyróżniają standardy wyceny przedsiębiorstw? Spośród analizowanych standardów właściwie wszystkie poza jednym (australijskim), który nie prezentuje żadnej klasyfikacji podejść lub metod wyceny, prezentuje anglosaski punkt widzenia na podejścia do wyceny dzielący podejścia do wyceny na dochodowe, porównawcze/rynkowe i majątkowe/kosztowe. Co ciekawe także standard niemiecki wpisuje się, choć nie wprost, w ten podział. Różnice pomiędzy poszczególnymi standardami w zakresie klasyfikacji podejść i metod wyceny tkwią w nazewnictwie, natomiast sens, intencje są generalnie tożsame.

Analizowane standardy wyceny przedsiębiorstw można podzielić na te, które w zakresie podejść i metod wyceny ograniczają się jedynie do ich specyfikacji oraz drobnych uwag oraz na standardy które zawierają także regulacje poświęcone szczegółom metodycznym poszczególnych podejść i metod wyceny. Do pierwszej grupy standardów należy zaliczyć standardy amerykańskie IBA, NACVA, standardy kanadyjskie, standardy chińskie, nowozelandzkie i australijskie oraz standardy międzynarodowe IACVA.

Odnosząc się do konkretnych przypadków w ramach pierwszej grupy amerykański standard wyceny IBA specyfikuje w różnych miejscach standardu takie podejścia do wyceny jak: dochodowe (ang. income approach), rynkowe/ porównawcze (ang. market approach), majątkowe (ang. asset/cost based approach) (punkt 7.5) i nie specyfikuje żadnej z metod w ramach wymienionych podejść. Jedyne uwagi dotyczą rozważań jakie powinien przeprowadzić ekspert aby rozstrzygnąć, które podejście jest właściw, a które nie w danym przypad$\mathrm{ku}^{14}$. Kolejny standard amerykański NACVA wyróżnia podejście majątkowe (ang. asset-based approach), rynkowe/porównawcze (market approach), docho-

${ }^{13}$ Zob. Nota Interpretacyjna NI 5, Wycena przedsiębiorstw, Powszechne Krajowe Zasady Wyceny (PKZW), XIX Krajowa Konferencja Rzeczoznawców Majątkowych, Udział rzeczoznawców majątkowych w wycenie przedsiębiorstw. Zasady dobrej praktyki zawodowej, Polska Federacja Stowarzyszeń Rzeczoznawców Majątkowych, Kielce 2010.

${ }^{14}$ Business Appraisal..., op. cit., s. 32-34. 
dowe (ang. income approach) lub kombinację tych podejść. Standard ten nakłada na wyceniającego konieczność dokonania profesjonalnej oceny i wyboru podejścia lub podejść oraz metody lub metod, które najlepiej odzwierciedlą wartość przedmiotu wyceny (punkt 3.6) ${ }^{15}$. Niewiele miejsca podejściom i metodom wyceny poświęca także standard kanadyjski ograniczając się jedynie do specyfikacji trzech podejść do wyceny: dochodowe (ang. income), kosztowe (ang. cost) i rynkowe/porównawcze (ang. market) ${ }^{16}$. W ramach podejścia dochodowego wyróżniono dwie metody, a mianowicie opartą na dochodach (ang. earnings method) oraz przepływach pieniężnych (ang. cash flow metod), w ramach podejścia kosztowego wyróżniono metodę skorygowanych aktywów netto (ang. adjusted net book value metod), a w ramach podejścia rynkowego wyróżniono metodę porównywalnych transakcji (ang. comparable transactions met$h o d)^{17}$. To co różni klasyfikację standardów kanadyjskich w zakresie podejść do wyceny od wymienionych wcześniej standardów amerykańskich to posługiwanie się terminem podejście kosztowe w miejsce podejścia majątkowego.

Dość minimalistyczny charakter w obszarze podejść i metod wyceny mają Standardy międzynarodowe IACVA. Standardy te wyróżniają podejścia majątkowe (ang. asset-based approach), rynkowe/porównawcze (ang. market approach), dochodowe (ang. income approach) oraz kombinację tych podejść. Standardy IACVA wymagają, aby w oparciu o profesjonalną ocenę dokonać wyboru podejść i metod, które w najlepszy sposób wskażą wartość przedmiotu wyceny. Standardy dopuszczają także regułę kciuka, ale nie może ona być jedyną użytą w wycenie metodą (punkt IV. F) ${ }^{18}$. Bardzo niewiele miejsca podejściom i metodom wyceny poświęcają standardy chińskie. Ograniczają się właściwie do dwóch konstatacji (punkt 5.12). Pierwsza dotyczy specyfikacji trzech podejść do wyceny: majątkowe (ang. asset-based approach), dochodowe (ang. income approach) i rynkowe/porównawcze (ang. market approach). Drugie zalecenie odnosi się do konieczności wykorzystywania więcej niż jednego podejścia i metody wyceny. Wg tych standardów oparcie się na jednej metodzie w ramach jednego podejścia może być niewystarczające ${ }^{19}$. Kolejnymi standardami, które niewiele miejsca poświęcają podejściom i metodom do wyceny są standardy nowozelandzkie. Standardy te ignorują klasyfikację na podejścia do wyceny ograniczając się do wyspecyfikowania możliwych do zastosowania metod: metodę DCF, kapitalizacji dochodów, kapitalizacji dywidend, metodę majątkową (ang. asset realisation), metodę porównawczą (ang. market comparison-based techniques) oraz inne rozpoznawalne metody bazujące na specyficz-

\footnotetext{
${ }^{15}$ Professional Standards..., op. cit., s. 8.

${ }^{16}$ Standard no 110, The Canadian Institute of Chartered Business Valuators, June 2009,

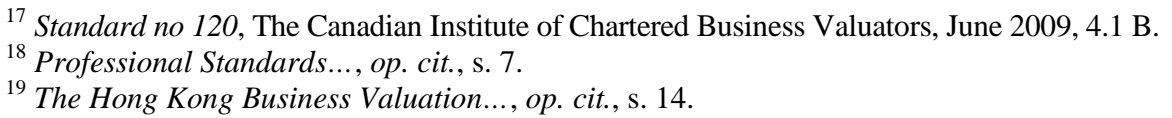
13.2. 
nych branżowych podejściach do wyceny i benchmarkach, spośród których wyceniający musi wybrać odpowiednie (punkt 29$)^{20}$.

Spośród wymienionych $\mathrm{w}$ tej grupie standardów najbardziej minimalistyczne w kwestii podejść i metod wyceny są standardy australijskie. Standardy te poruszają kwestie podejść i metod wyceny jednak nie wymieniają ani nie odnoszą się do żadnego z nich. Standardy te w tym zakresie jedynie narzucają konieczność rozważenia i uzasadnienia wyboru podejść i metod wyceny (punkt 5.4).

Do drugiej grupy standardów, które ingerują w metodykę podejść i metod wyceny należy zaliczyć standardy amerykańskie ASA i AICPA, standard niemiecki, standard polski oraz standardy międzynarodowe IVSC. Zarówno standardy amerykańskie, jak i międzynarodowy standard wyceny IVSC, standard polski i pośrednio standard niemiecki wyróżniają i nakazują wyceniającemu rozważenie zastosowania trzech najbardziej popularnych podejść do wyceny. Istnieją między nimi jedynie drobne różnice w nazewnictwie. Standardy międzynarodowe IVSC wyróżniają podejścia majątkowe (ang. asset-based business valuation approach), dochodowe (ang. income capitalisation approach to business valuation), rynkowe/porównawcze (ang. market approach to business valuation $)^{21}$. Jeden z najbardziej rozbudowanych standardów wyceny AICPA wyróżnia (punkt 31) podejście dochodowe (ang. Income/Income-based approach), majątkowe lub kosztowe (ang. asset/asset-based approach or cost approach) oraz rynkowe/porównawcze (ang. market/market-based approach) ${ }^{22}$. Z kolei standardy amerykańskie ASA posługują się takimi terminami jak majatkowe (ang. asset based approach), dochodowe (ang. income approach) i porównawcze/rynkowe (ang. market approach) ${ }^{23}$. Najmniej ingerujący w metody wyceny w tej grupie standardów polski standard wyceny wyróżnia także trzy podejścia: majątkowe, dochodowe, i porównawcze (punkt 8.1) ${ }^{24}$.

Standardy amerykańskie, jak i standardy kanadyjskie, ale także międzynarodowe standardy wyceny IACVA opierają się na tym samym słowniku terminów International Glossary of Business Valuation Terms, który definiuje podejścia (ang. valuation approach/appraisal approach) i metody wyceny (ang. valuation method/appraisal method):

- Podejście majątkowe (ang. asset approach/asset-based approach) - definiowane jako sposób określania wartości wynikającej z przedsiębiorstwa/ przedsięwzięcia biznesowego, wkładów właścicieli lub papierów wartościo-

\footnotetext{
${ }^{20}$ Independent Business Valuation Engagements..., op. cit., s. 910.

${ }^{21}$ Międzynarodowe standard wyceny w osobnych standardach regulują wycenę przedsiębiorstwa, biznesu (Note No. 6.6) i wycenę aktywów niematerialnych (Note Np. 6.4), zob. International Valuation Standards..., op. cit.

${ }^{22}$ Valuation of a Business...., op. cit., s. 16.

${ }^{23}$ ASA Business Valuation Standards...., op. cit., s. 9-13.

${ }^{24}$ Nota Interpretacyjna NI 5, Wycena przedsiębiorstw..., op. cit., s. 306-309.
} 
wych, wykorzystujący jedną lub więcej metod bazujących na wartości aktywów netto ponad zobowiązania/aktywów skorygowanych o zobowiązania ${ }^{25}$.

- Metoda skorygowanych aktywów netto (ang. adjusted book value method/adjusted book value method) - metoda wyceny w ramach podejścia majątkowego, gdzie wszystkie aktywa i zobowiązania (biorąc pod uwagę także te, które są poza bilansem) są korygowane do ich godziwej wartości rynkowej (W Kanadzie w oparciu o założenie kontynuacji działalności) ${ }^{26}$.

- Podejście kosztowe (ang. cost approach) - sposób określania wartości indywidualnych aktywów przez kwantyfikowanie kwoty pieniędzy wymaganych do zastapienia przyszłych usług możliwych do uzyskania z tych aktywów ${ }^{27}$.

- Podejście dochodowe (ang. income approach/income-based approach) sposób określania wartości wynikającej z przedsiębiorstwa/przedsięwzięcia biznesowego, wkładów właścicieli papierów wartościowych lub aktywów niematerialnych wykorzystujący jedną lub więcej metod, które konwertują przewidywane ekonomiczne korzyści w obecną pojedynczą kwotę ${ }^{28}$.

- Metoda kapitalizacji dochodów (ang. capitalization of earnings method) - metody w ramach podejścia dochodowego, gdzie ekonomiczne korzyści z reprezentatywnego pojedynczego okresu są konwertowane W wartość poprzez dzielenie przez stopę kapitalizacji ${ }^{29}$.

- Podejście porównawcze/rynkowe (ang. market approach/market-based approach) - sposób określania wartości wynikającej z przedsiębiorstwa/ przedsięwzięcia biznesowego, wkładów właścicieli, papierów wartościowych lub aktywów niematerialnych wykorzystujący jedną lub więcej metod, które porównują przedmiot wyceny z podobnym przedsiębiorstwem/przedsięwzięciem biznesowym, wkładami właścicieli, papierami wartościowymi lub aktywami niematerialnymi, które zostały sprzedane ${ }^{30}$.

Większość wymienionych standardów - wskazując podejścia i metody jakie powinien rozważyć ekspert - nie dokonuje ich gradacji, oceny przydatności w określonych sytuacjach. Cześć standardów dość szczegółowo odnosi się do wszystkich podejść mimo, że jak zaznaczono to np. w punkcie 32 standardów AICPA szczegółowe wskazówki dotyczące podejść i metod oraz ich zastosowania wykraczają poza zakres tych standardów.

${ }^{25}$ International Glossary of Business Valuation Terms, w Valuation of a Business, Business Ownership Interest, Security, or Intangible Asset, Statement on Standards for Valuation Services Issued by the AICPA Consulting Services Executive Committee, American Institute of Certified Public Accountants, Inc., New York 2007, s. 41.

${ }^{26}$ Ibidem, s. 41.

${ }^{27}$ Ibidem, s. 43.

${ }^{28}$ Ibidem, s. 45.

${ }^{29}$ Ibidem, s. 42.

${ }^{30}$ Ibidem, s. 46. 
Jak mocno ingerują w metodykę poszczególnych podejść i metod wyceny te standardy wyceny przedsiębiorstw, które nie ograniczają się jedynie do ich specyfikacji? Jakie są rozbieżności na tym polu pomiędzy analizowanymi standardami? Na te pytania próbują odpowiedzieć następne punkty artykułu.

\section{PODEJŚCIE DOCHODOWE}

W ramach podejścia dochodowego standardy AICPA wyróżnić można dwie metody: kapitalizacji korzyści (ang. capitalization of benefits metod) i dyskontowania przyszłych korzyści (ang. discounted future benefits metod). Uwagi tych standardów w kwestii metod wyceny ograniczają się do zakresu rozważań jakie powinien rozważyć ekspert w procesie wyceny. W ramach metody kapitalizacji korzyści (ang. capitalization of benefits metod) standardy te wskazują, że wyceniający powinien rozważyć (33.a.): normalizujące dostosowania, jednorazowe przychody i koszty, podatki, strukturę kapitału i koszty finansowania, odpowiednie inwestycje kapitałowe, pozycje niepieniężne, oceny jakościowe istotne dla ryzyka wykorzystywanego w obliczaniu stopy dyskontowej i stopy kapitalizacji, oczekiwane zmiany w przyszłych korzyściach (w zakresie np. dochodów lub przepływów pieniężnych). W ramach metody dyskontowania przyszłych korzyści standardy AICPA nakazują rozważyć również takie kwestie jak (33b.): założenia do przewidywań i do projekcji, projektowanie dochodów lub przepływów pieniężnych, wartość końcową (ang. terminal value). Standardy te określają także zakres rozważań jakie należy przeprowadzić w przypadku wyceny aktywów niematerialnych, tj.: pozostały użyteczny okres życia danego aktywu, bieżące i przewidywane przyszłe wykorzystanie aktywu, przypisane prawa, pozycję danego aktywu w ramach jego cyklu życia, odpowiednią stopę dyskontową dla aktywów niematerialnych, odpowiedni kapitał, niezbędne wydatki na badania i rozwój lub marketing dla wzmocnienia aktywów niematerialnych w obecnym stanie, alokację dochodu $\mathrm{w}$ aktywach niematerialnych, korzyści podatkowe związane $\mathrm{z}$ amortyzacją, należności licencyjne, zwolnienia $\mathrm{z}$ opłat licencyjnych (33.c.) ${ }^{31}$.

Podobny zakres ingerencji w metodykę podejścia dochodowego można znaleźć w standardach ASA. Czwarta część tych standardów dotyczy podejścia dochodowego, które definiowane jest jako sposób określenia wartości przedsiębiorstwa, wkładów właścicieli, papierów wartościowych lub aktywów niematerialnych, wykorzystującego jedną lub więcej metod, które antycypując korzyści konwertują je na wartość. W ramach podejścia dochodowego standardy wymieniają metody oparte na kapitalizacji przyszłych korzyści i dyskontowaniu przyszłych korzyści. Standardy ASA zaznaczają, że antycypowane korzyści wyko-

\footnotetext{
${ }^{31}$ Valuation of a Business...., op. cit., s. 16-18.
} 
rzystywane w podejściu dochodowym są wyrażane w postaci pieniężnej i mogą być reprezentowane przez takie pozycje jak dywidendy lub różne formy dochodów lub przepływów pieniężnych. Standardy te wskazują także, ze antycypacja korzyści powinna być określana przez rozważenie takich kwestii jak natura, struktura kapitałowa i historyczna działalność, oczekiwane przyszłe perspektywy przedsiębiorstwa i odpowiednich branż oraz czynniki ekonomiczne. Konwersja antycypowanych korzyści na wartość bierze pod uwagę oczekiwany wzrost i czas trwania korzyści, ryzyko związane ze strumieniem korzyści oraz zmienną wartość pieniądza w czasie. Dla określenia czynnika kapitalizacji lub stopy dyskonta ekspert powinien rozważyć takie czynniki jak stopy procentowe, oczekiwane stopy zwrotu przez inwestorów z alternatywnych inwestycji i specyficzne ryzyko związane z antycypowanymi korzyściami ${ }^{32}$.

Podobny do standardów AICPA i standardów ASA zakres ingerencji prezentują międzynarodowe standardy wyceny IVSC, które definiują podejście dochodowe (ang. income capitalization approach) jako określanie wartości przedsiębiorstwa, wkładów właścicieli, papierów wartościowych przez obliczenie wartości obecnej antycypowanych korzyści i wyróżniają dwie powszechne/ popularne metody: kapitalizację dochodu (ang. capitalisation of income) i zdyskontowane przepływy pieniężne (ang. discounted cash flow - DCF) lub zdyskontowane dywidendy (ang. dividents method) jako drugą metodę (5.14.2.1). W kolejnych punktach standardy międzynarodowe IVSC prezentują metodykę poszczególnych metod w ramach podejścia dochodowego, wskazując na stanowisko teoretyczne i praktyczne. Standardy przestrzegają np. że stopa dyskonta musi być odpowiednia do wykorzystywanych przepływów pieniężnych, a parametry takie jak stopa kapitalizacji czy też stopa dyskonta powinny być ustalone w oparciu o dane rynkowe (5.14.2.1.3). Standardy międzynarodowe IVS dostarczają także wskazówek metodycznych w zakresie konieczności analizowania szeregu czynników, które mogą mieć wpływ na antycypowanie dochodu lub innych korzyści dla potrzeb wyceny $(5.14 .2 .2)^{33}$.

Polski standard wyceny definiuje podejście dochodowe oraz wyróżnia trzy metody: zdyskontowanych przepływów pieniężnych, zdyskontowanych zysków i zdyskontowanych dywidend (punkt 8.3). W zakresie metod dochodowych standard ten wskazuje na konieczność dostosowania okresu projekcji dochodów ekonomicznych do planowanego okresu działalności lub do fazy stabilnych dochodów. Dodatkowo standard zwraca uwagę na konieczność właściwego określenia kosztu kapitału oraz dokonania korekt o aktywa i pasywa które nie mają operacyjnego charakteru ${ }^{34}$.

Za najbardziej ingerujące w metodykę w zakresie metod wykorzystywanych w wycenie można uznać niemieckie standardy wyceny przedsiębiorstw. Stan-

\footnotetext{
${ }^{32}$ ASA Business Valuation Standards...., op. cit., s. 10-11.

${ }^{33}$ International Valuation Standards....., op. cit., s. 6.6.9-6.6.10.

${ }^{34}$ Nota Interpretacyjna..., op. cit., s. 306-307.
} 
dardy te klasyfikują metody z punktu widzenia ich ważności, wiarygodności i przydatności w wycenie. Przykładem może być regulacja (punkt 2.1) podkreślająca rolę siły dochodowej przedsiębiorstwa w wycenie przedsiębiorstwa, która generalnie determinowana jest przez jego zdolność do generowania przepływów pieniężnych dla właścicieli. Stąd też standard ten akcentuje, że dobrym podejściem do wyceny przedsiębiorstw $\mathrm{w}$ praktyce są modele zdyskontowanych dywidend oraz zdyskontowanych przepływów pieniężnych. Tym metodom przeciwstawiają podejście majątkowe (ang. asset-based approach), które nie odzwierciedla wartości tworzonej przez dane przedsięwzięcie biznesowe. Stąd też znaczna część standardów poświęcona jest podejściu dochodowemu (choć ten termin nie występuje w standardach niemieckich). Dla potrzeb metod wyceny zaliczanych do podejścia dochodowego standardy niemieckie nakazują branie pod uwagę tych czynników sukcesu przedsiębiorstwa, które istnieją na dzień wyceny (4.4.2.2.), jak również efektów synergicznych oraz efektów pseudo synergicznych i ich wpływu na wycenę (4.4.2.2.). W siódmej rozbudowanej części standardu niemieckiego zatytułowanej metody wyceny opisano metodę zdyskontowanych dywidend, metodę DCF, metodę likwidacyjną oraz podejście porównawcze, przy czym szczegółowo odniesiono się jedynie do podejścia dochodowego. Osobne punkty w ramach tej części poświęcone są metodzie zdyskontowanych dywidend oraz metodom DCF. Ostatni punkt tej części poświęcony jest uwagom związanym z wiarygodnością wyceny. Metoda zdyskontowanych dywidend opisana jest $\mathrm{w}$ standardzie niemieckim bardzo szczegółowo $\mathrm{w}$ punkcie 7.2. Opisano w nim generalną procedurę oraz takie czynności jak: dostosowanie historycznych rachunków zysków i strat, planowanie wydatków i wpływów, określanie przepływów pieniężnych, projekty finansowe, przewidywanie stopy zwrotu, określanie dodatkowych korzyści z mniej istotnych aktywów (które nie mają charakteru operacyjnego), określanie stopy dyskontowej w sytuacji określania wartości obiektywnej i subiektywnej. W kolejnym punkcie (7.3.) równie wiele miejsca poświęcono szczegółom metodycznym metody DCF. W punkcie tym wyróżniono trzy sposoby ustalenia wartości wkładów właścicieli: pośredni wykorzystujący przepływy pieniężne dla wszystkich dostarczycieli kapitału i koncepcję WACC (ang. weighted average cost of capital), następnie metodę APV (ang. adjusted present value method), jak i metodę bezpośrednią bazującą na przepływach pieniężnych dla właścicieli oraz koszcie kapitału własnego. W tym kontekście detalicznie opisano procedury w zakresie określania średniego ważonego kosztu kapitału, przyszłych wolnych przepływów pieniężnych, wartości rezydualnej, wartości oraz kwestii podatku dochodowego właścicieli przedsiębiorstwa. W porównaniu do innych standardów wyceny standard niemiecki w zakresie podejścia dochodowego ma wybitnie charakter podręcznikowy i mocno ingeruje w kwestie metodyki dopuszczonych metod wyceny przed- 
siębiorstw oraz poszczególnych modeli, parametrów wykorzystywanych w tych $\operatorname{metodach}^{35}$.

\section{PODEJŚCIE PORÓWNAWCZE}

W zakresie podejścia porównawczego/rynkowego standardy AICPA wyróżniają trzy najczęściej wykorzystywane metody w wycenie przedsiębiorstw, wkładów właścicieli lub papierów wartościowych:

- metodę opartą na wytycznych ze spółek giełdowych (ang. guideline public company method),

- metodę opartą na wytycznych z transakcji na rynku prywatnym (ang. guidline company transactions method),

- metodę opartą na wytycznych wynikających z dotychczasowej sprzedaży wkładów właścicieli w wycenianym przedsiębiorstwie (ang. guideline sales of interests in subject entity).

Standardy AICPA wyróżniają także trzy metody wyceny aktywów niematerialnych:

- metodę porównywalnych niekontrolowanych transakcji (ang. comparable uncontrolled transactions metod),

- metodę porównywalnej marży zysku (ang. comparable profit margin method),

- metodę zwolnień $\mathrm{z}$ opłat za korzystanie $\mathrm{z}$ aktywów niematerialnych/alternatywnych opłat za korzystanie z aktywów niematerialnych (ang. relief from royalty method).

Stosując powyższe metody do wyceny standardy AICPA narzucają konieczność przeanalizowania: jakościowych i ilościowych porównań, transakcji i cen zrealizowanych na zasadach rynkowych, daty i adekwatność danych rynkowych. Standardy AICPA odnoszą się również do reguły kciuka, którą nie uznają za metodę wyceny. Stąd też standardy te stoją na stanowisku, że reguła kciuka oraz branżowe wskaźniki benchmarkowe nie mogą być jedynym sposobem określania wartości przedmiotu wyceny ${ }^{36}$.

Kolejne standardy ASA całą część piątą poświęcają podejściu rynkowemu (market approach). Regulacje te wskazują, że korzystanie z podejścia rynkowego wymaga uzasadnienia podstawy porównania. Stąd też należy rozważyć:

- Czy istnieje wystarczające podobieństwo ilościowe i jakościowe charakterystyk pomiędzy benchmarkiem a przedmiotem wyceny (inwestycja)?

- Czy znana jest kwota i czy można zweryfikować dane o podobnej inwestycji (podobnym przedmiocie jak przedmiot wyceny)?

\footnotetext{
${ }^{35}$ IDW Standard: Principles for the Performance of Business Valuations...., op. cit., s. 4-28.

${ }^{36}$ Valuation of a Business...., op. cit., s. $18-19$.
} 
- Czy cena podobnej inwestycji była obserwowana w warunkach rynkowej transakcji czy też w sytuacji przymusowej, awaryjnej?

Według tych standardów w związku z tym, że istnieje wiele wskaźników, które mogą być wykorzystane w podejściu rynkowym to ekspert powinien rozważyć wszystkie istotne czynniki, które mogą wpływać na ten wybór, jednocześnie być ostrożnym w takich kwestiach jak: ków,

- dobór danych źródłowych wykorzystywanych w obliczeniach wskaźni-

- dobór okresu i metod uśredniania wykorzystywanych do obliczania danych źródłowych,

- obliczanie wskaźników wyceny,

- termin sporządzenia danych związanych z ceną i wykorzystywanych we wskaźnikach w kontekście efektywnej daty wyceny,

- wskaźniki wyceny - czy zostały dobrane i zastosowane w odniesieniu do danych źródłowych przedmiotu wyceny?

Podobnie jak standardy AICPA, standardy ASA odnoszą się także do reguły kciuka (ang. rules of thumb), która może być wykorzystana w określeniu wartości przedmiotu wyceny. Jednak wg standardów ASA wskazania wynikające z tej metody nie mogą mieć zasadniczego znaczenia dla wyników wyceny, chyba, że są potwierdzone innymi metodami wyceny ${ }^{37}$.

Polski standard wyceny definiuje podejście porównawcze, ale nie wyróżnia żadnych metod $w$ ramach tego podejścia (punkt 8.4). Wymienia natomiast trzy rodzaje mnożników (mnożniki oparte na wartości rynkowej, mnożniki oparte na wartości całego przedsiębiorstwa oraz mnożniki oparte na charakterystycznych dla danego sektora wielkościach) jakie można zastosować w podejściu porównawczym. Standard ten zwraca uwagę także na wybrane problemy związane ze stosowaniem tego podejścia. Wg tej regulacji wycena oparta na mnożnikach sektorowych nie może stanowić jedynej metody wyceny. Podobnie jak w standardach międzynarodowych IVSC oraz amerykańskich standardach ASA, standard polski określa konieczność zbierania aktualnych i wiarygodnych danych, stosowania jednolitej metodyki $\mathrm{w}$ określaniu parametrów dla wycenianego przedsiębiorstwa i dla przedsiębiorstw porównywalnych, uwzględnienia elementów nieoperacyjnych, nadzwyczajnych, jednorazowych, dokonania korekt z tytułu kontroli, płynności i wielkości oraz korekt o inne czynniki, które zaburzają porównywalność ${ }^{38}$.

Międzynarodowe standardy wyceny IVSC definiują podejście rynkowe jako porównywanie przedmiotu wyceny do podobnych przedsiębiorstw, wkładów właścicieli, papierów wartościowych, które są sprzedawane na otwartym rynku (5.14.1.1). Standardy wyróżniają trzy powszechne, popularne źródła danych w podejściu porównawczym: rynek papierów wartościowych, rynek prze-

\footnotetext{
${ }^{37}$ ASA Business Valuation Standards...., op. cit., s. 12-13.

${ }^{38}$ Nota Interpretacyjna NI 5, Wycena przedsiębiorstw..., op. cit., s. 307-308.
} 
jęć i dotychczasowe transakcje na przedmiocie wyceny (5.14.1.2). Także w zakresie tego podejścia standardy międzynarodowe IVS zawierają liczne wskazówki metodyczne w zakresie doboru zbliżonych biznesów do przedmiotu wyceny (5.14.1.3). W tym zakresie standardy zwracają uwagę na takie kwestie jak: ten sam rodzaj branży lub branży charakteryzującej się tymi samymi zmiennymi, charakterystykę jakościową i ilościową przedmiotu wyceny oraz przedmiotu wybranego do porównań, liczba/wielkość i sprawdzalność danych z podobnego biznesu. Wg standardów międzynarodowych IVSC zastosowanie podejścia rynkowego musi być sporządzone w przejrzysty sposób i nie może być mylące. Standardy te zawierają liczne przestrogi odnoszące się do podejmowanych działań w ramach podejścia rynkowego, dotyczą one m. in. porównywalności wykorzystywanych wskaźników, punktu widzenia wartości przeciętnych, dat, zdarzeń jednorazowych i aktywów nieoperacyjnych, różnic w ryzyku, poziomu kontroli, poziomu płynności przedmiotu wyceny i przedmiotu wybranego do porównań. W sytuacji wykorzystywania w podejściu rynkowym wcześniejszych transakcji standardy wymagają, aby przeprowadzić konieczne dostosowania, które będą uwzględniały upływ czasu, zmiany warunków w gospodarce, branży i danym biznesie (5.14.1.4.1-5.14.1.4.11). Standardy IVSC odnoszą się również do niepotwierdzonych reguł wyceny lub reguły kciuka, które mogą być użyteczne w wycenie, ale nie powinno się im nadawać istotnej wagi, jakkolwiek mogą być pokazywane jeśli kupujący i sprzedający na nich polegają $(5.14 .1 .6)^{39}$.

Zmiany, jakie zaszły w umiejscowieniu podejść do wyceny w standardach międzynarodowych IVSC w stosunku do poprzedniej edycji regulacji, mogą sugerować, że podejście porównawcze zostało dowartościowane poprzez przesunięcie na pierwsze miejsce omawianych podejść, natomiast podejście majątkowe wymieniane do tej pory jako pierwsze zostało umieszczone na końcu omawianych podejść. Może to świadczyć o przesunięciu akcentów w ramach tej regulacji. Bardziej dosadnie w zakresie ważności poszczególnych podejść i metod wyceny „wypowiada” się standard niemiecki, który metody w ramach podejścia porównawczego i majątkowego sytuuje niżej w hierarchii niż podejście dochodowe. W przeciwieństwie do standardów niemieckich amerykańskie standardy ASA, AICPA, jak też większość innych standardów z tego zakresu nie wskazują preferowanego podejścia, metody i nie dezawuują metod porównawczych.

W punkcie (2.4.) niemiecki standard odnosi się do problemu wyceny przedsiębiorstw przy użyciu podejścia porównawczego wskazując, że bieżące ceny akcji przedsiębiorstw mogą dostarczać wystarczająco porównywalnych i aktualnych ocen, ale nie mogą one zastapić wyceny przedsiębiorstwa (rozumianej jako wyceny przy użyciu podejścia dochodowego). Tym samym standardy niemieckie w pewnym stopniu dystansują się od podejścia porównawczego w wycenie przedsiębiorstw. Także trzeci rozdział tego standardu poświęcony jest relacji

${ }^{39}$ International Valuation Standards..., op. cit., s. 6.6.8-6.6.9. 
wartości akcji przedsiębiorstwa ustalonego wg standardu wyceny IDW oraz cen giełdowych akcji. Standardy niemieckie każą rozróżniać wartość przedsiębiorstwa, akcji w przedsiębiorstwie ustaloną w oparciu o pryncypia ustalone przez Standardy IDW od cen giełdowych czy też rynkowej kapitalizacji determinowanej przez ceny giełdowe. Zwracają jednak uwagę na tylko jeden powód tych ewentualnych różnic. Wg tych standardów wycena przeprowadzona wg standardów bazuje na szczegółowych analizach danych takich jak biznes plan, budżet, które nie są dostępne uczestnikom rynku kapitałowego. Standardy niemieckie nie odnoszą się natomiast do innych ewentualnych przyczyn różnic takich jak $n p$. behawioralne efekty na rynkach finansowych czy też kierowanie się analizą techniczną przez wielu uczestników rynku w przeciwieństwie do wyceniających kierujących się analizą fundamentalną. Mimo iż, jak można sądzić, standardy niemieckie wyżej cenią uzyskane wyniki wyceny oparte na podejściu dochodowym zgodnym ze standardem IDW niż wyceny uzyskane metodą porównawczą/rynkową, to zalecają, jeśli to możliwe, używanie giełdowych cen akcji w wycenie dla oceny wiarygodności wartości przedsiębiorstwa lub akcji określonych według standardu IDW, wziąwszy pod uwagę, że ceny giełdowe mogą być pod wpływem wielu czynników takich jak np. niewielka liczba akcji w obrocie, specyficzna sytuacja rynkowa. $Z$ drugiej strony, wg standardu niemieckiego różnice miedzy wartością ustaloną w oparciu o przyszłe dochody i ceną rynkową akcji nie mogą być podstawą do krytycznego przeglądu danych wejściowych i założeń poczynionych w wycenie (przy użyciu podejścia dochodowego). Ten brak konsekwencji $\mathrm{w}$ opisywaniu relacji wartości uzyskanej w procesie wyceny przy użyciu metod dochodowych i metod porównawczych odwołujących się do ceny rynkowej akcji związany jest być może z tym, że jak zwracają uwagę standardy niemieckie to, zgodnie z niemieckimi przepisami w specyficznych przypadkach wyceny przedsiębiorstw za wartość minimalną wkładów właścicieli przyjmowana jest cena giełdowa akcji jeśli jest wyższa niż wartość uzyskana wg modelu zdyskontowanych dywidend. Przy czym według standardu tego typu sytuacja nie ma zastosowania w przypadkach, gdy cena giełdowa akcji jest efektem niskiej płynności czy też manipulacji. Standard niemiecki jednak nie precyzuje kiedy ekspert może uznać, że płynność akcji jest zbyt mała lub też mamy do z manipulacją cen. Standard niemiecki odnosi się do podejścia porównawczego także w punkcie 7.5., w którym podnosi problem wiarygodności wyceny. Podejście to wg standardu niemieckiego mimo, że określone jest mianem uproszczonej wyceny, to może być wykorzystane dla oceny wiarygodności wykorzystanych metod wyceny takich jak DCF czy też metoda zdyskontowanych dywidend pod warunkiem, że ceny rynkowe akcji są dostępne. Jednocześnie standard informuje, że w praktyce podejście porównawcze jest często używane dla uproszczonej wyceny w przypadku małych i średnich przedsiębiorstw, jednak to nie oznacza, iż takie podejście może być substytutem wyceny przedsiębiorstw przeprowadzanej wg standardu IDW 1 (czyli wyceny według podejścia 
dochodowego). Jeśli standard niemiecki uznaje, że można badać wiarygodność dwóch metod dochodowych poprzez podejście porównawcze to tym samym oznacza, że podejścia porównawcze są wzorcem, punktem odniesienia dla innych metod. W takim razie niezrozumiałe, niespójne wydaje się stanowisko standardu, który nadaje metodom porównawczym jedynie funkcję pomocniczą. Podejście porównawcze poruszane jest jeszcze w ramach punktu 8.3.3. opisującego generalne ograniczenia w dostępie do informacji, gdzie ustosunkowano się do takich kwestii jak: dostosowanie historycznych rezultatów uzyskiwanych przez przedsiębiorstwo, analizowanie siły dochodowej przedsiębiorstwa, uproszczona wycena, wartość aktywów netto. Pod hasłem uproszczona wycena (albo lepiej użyć określenia uproszczone określanie ceny do terminu simplified pricing) odniesiono się do metod multiplikacyjnych (dochodowych, sprzedażowych, produktowo-ilościowo zorientowanych) (punkt 8.3.4.). W punkcie tym standard informuje, że te metody multiplikacyjne są używane (nie mówi, czy powinny czy też nie) szczególnie dla określenia cen rynkowych małych jednostek usługowych. Standard zwraca jednocześnie uwagę, że to podejście znacząco bazuje na wartości urynkowionej bazy klientów, a dla wartości rynkowej profesjonalnych praktyk istotną rolę odgrywa transferowalność list klientów ${ }^{40}$.

\section{PODEJŚCIE MAJĄTKOWE}

W zakresie podejścia majątkowego i podejścia kosztowego standardy AICPA wskazują obszary, które powinny być przedmiotem rozważań przez wyceniającego. W przypadku metody skorygowanych aktywów netto wyceniający powinien rozważyć następujące informacje w nawiązaniu do podstawowego założenia wyceny: identyfikację aktywów i pasywów, indywidualną lub zagregowaną wartość aktywów i pasywów, koszty likwidacji jeśli maja zastosowanie. Wg standardów AICPA podejście kosztowe ma zastosowanie w wycenie aktywów niematerialnych (ang. intangible assets). W przypadku wykorzystania metod $\mathrm{w}$ ramach podejścia kosztowego do wyceny aktywów niematerialnych wyceniajaccy powinien rozważyć rodzaj kosztu jaki powinien być zastosowany np. koszt reprodukcji/odtworzenia, koszt zastapienia, odpowiednia forma umorzenia, starzenie się oraz pozostały czas użytkowania aktywów niematerialnych $^{41}$.

Standardy ASA w trzeciej części wiele uwagi poświęcają podejściu majątkowemu w wycenie. Standardy uznają to podejście jako jedną z możliwych dróg do określenia wartości przedsiębiorstwa, wkładów właściciela, papierów wartościowych lub aktywach niematerialnych, która wykorzystuje jedną lub więcej

\footnotetext{
${ }^{40}$ IDW Standard: Principles for the Performance of Business Valuations..., op. cit., s. 6-33.

${ }^{41}$ Valuation of a Business..., op. cit., s. 18.
} 
metod bazujących na wartości aktywów netto. Standardy ASA - jak również standardy międzynarodowe IVS (punkt 5.14.3.1) - zwracają uwagę, że podejście majątkowe $\mathrm{w}$ wycenie przedsiębiorstw może mieć analogiczny charakter do podejścia kosztowego $\mathrm{w}$ innych obszarach wyceny. Wg standardów ASA zastosowanie podejścia majątkowego w wycenie powinno być rozważane w przypadku przedsiębiorstw, które mają charakter inwestycyjny lub są holdingiem $\mathrm{w}$ obszarze nieruchomości oraz $\mathrm{w}$ przypadkach innych przedsiębiorstw, kiedy założenie wyceny jest inne niż kontynuacja działalności. Wycena szczególnych rodzajów wkładów właścicieli w przedsiębiorstwie może lub nie musi wymagać wykorzystania podejścia majątkowego. Wg tych standardów podejście majątkowe nie może być jedynym (sole) podejściem wykorzystanym w wycenie, w której założono kontynuację działalności w przedsiębiorstwach o charakterze operacyjnym (prowadzących działalność polegająca na wytwarzaniu, sprzedaży lub handlu produktami lub usługami). Jak się wydaje standard dostrzega historyczny kontekst podejścia majątkowego oraz to, że wielu sprzedających i kupujących zwykle wykorzystujących to podejście będzie nadal chciało wiedzieć jaką wartość pokazuje to podejście. W takich sytuacjach wyceniający powinien wspierać ten wybór mając jednak na uwadze to, że nie może to być jedyny punkt widzenia na wartość przedsiębiorstwa ${ }^{42}$.

Standardy międzynarodowe IVSC wiele miejsca poświęcają podejściu majątkowemu w punkcie 5.14.3.2. Wskazują, że podejście majątkowe opiera się na regule substytucji zgodnie z którą dane aktywo jest warte nie więcej niż mógłby wynieść koszt wymiany wszystkich jego części składowych. Wg standardów międzynarodowych IVSC podejście majątkowe powinno być rozważane w przypadku wyceny kontrolnych udziałów w jednostce biznesowej, która jest inwestycją, holdingiem w sektorze nieruchomości (property business) lub w sektorze rolniczym lub też w sytuacji kiedy wyceniany biznes jest przy założeniu innym niż kontynuacji działalności. Podobnie jak w standardy ASA standardy międzynarodowe IVSC stoją na stanowisku, że podejście majątkowe nie może jedynym wykorzystywanym podejściem w ocenie części operacyjnej biznesu przy założeniu kontynuacji działalności chyba, że jest zwykle/zwyczajowo wykorzystywana przez sprzedających i kupujących. W tego typu sytuacjach wyceniający musi wspierać wybór takiego podejścia (5.14.3.5). W kolejnych regulacjach standardy międzynarodowe IVSC zawierają kolejne wskazówki metodyczne $\mathrm{w}$ zakresie stosowania podejścia majątkowego. Wskazują np. że w sytuacji kiedy wyceniana jest działalność operacyjna nie w oparciu o założenie kontynuacji działalności to aktywa powinny odzwierciedlać wartość rynkową zakładającą skrócony okres czasu ekspozycji na rynek, a wszystkie koszty sprzedaży aktywów lub zamknięcia biznesu muszą być brane pod uwagę w tym typie wyceny. Standardy te zwracają też uwagę na to, że wartości niematerialne - takie jak goodwill - mogą nie mieć wartości w tego typu okolicznościach,

\footnotetext{
${ }^{42}$ ASA Business Valuation Standards..., op. cit., s. 9.
} 
jednak inne aktywa niematerialne - takie jak patenty, znaki towarowe itp. - mogą zachować, utrzymać swoją wartość (5.14.3.6). Standardy nakazują, aby w przypadku wyceny holdingu, który posiada nieruchomości przynoszące dochód, wartość rynkowa powinna być ustalona dla każdej z nieruchomości z osobna (5.14.3.7). Standardy międzynarodowe IVSC zwracają także uwagę, że w sytuacji wyceny holdingu inwestycyjnego wyceniane papiery wartościowe, zarówno te, które są notowane jak i nie notowane na rynkach papierów wartościowych, moga wpływać takie czynniki jak płynność i ich wielkość, co może oznaczać, ze ich wartość będzie różnić się w zależności od cen notowanych na rynku $(5.14 .3 .8)^{43}$.

Regulacja polska definiuje podejście majątkowe oraz wyróżnia w jego ramach następujące metody: wartości skorygowanych aktywów netto, wartości likwidacyjnej oraz wartości odtworzeniowej (punkt 8.2). Nota zwraca uwagę, że metody te nie uwzględniają synergii pomiędzy składnikami przedsiębiorstwa oraz, że w wycenie przy użyciu tych metod należy uwzględnić aktywa i zobowiązania pozabilansowe ${ }^{44}$.

Standard niemiecki IDW $\mathrm{w}$ niewielkim stopniu odnosi się do podejścia majątkowego. Zaledwie jeden krótki punkt standardu poświęcono określaniu wartości likwidacyjnej przedsiębiorstwa (punkt 7.4.). W regulacji tej określono, że ten sposób wyceny może być zastosowany w sytuacji, gdy dochody przedsiębiorstwa są na tyle słabe, że wartość likwidacyjna przedsiębiorstwa jest wyższa niż przy założeniu kontynuacji działalności. Procedurę określania tej wartości zawarto w krótkim wyjaśnieniu według którego wartość tą określa się jako obecną wartość z wpływów netto uzyskanych ze zbycia aktywów pomniejszonych o zobowiązania i koszty likwidacji oraz skorygowaną o ewentualne podatki. W ósmej części standard niemiecki prezentuje stanowisko odnośnie wartości aktywów netto (ang. net assets value), opisując je jako wartość wydatków jakie należałoby ponieść, aby odtworzyć substancję materialną i niematerialną przedsiębiorstwa uwzględniając ich dotychczasowe zużycie i przewidywany okres użytkowania (punkt 8.4.). Wskazuje również, że ze względu na trudności napotykane przy określeniu wartości aktywów, które nie są uwzględniane w bilansie przedsiębiorstwa to zwykle jest obliczana jako częściowa wartość odtworzeniowa netto (ang. net partial replacement value). Standard zaznacza, że wartość uzyskana $\mathrm{w}$ ten sposób nie ma bezpośredniego związku z przyszłymi przepływami pieniężnymi, w związku z czym nie jest istotnym czynnikiem dla określania wartości przedsiębiorstwa. Stąd też wartość aktywów netto jest wyłącznie ustalana w sytuacji, kiedy jest określona w specyficznych warunkach wynikających z umowy ${ }^{45}$.

\footnotetext{
${ }^{43}$ International Valuation Standards..., op. cit., s. 6.6.10-6.6.11..

${ }^{44}$ Zob. Nota . NI 5, Wycena przedsiębiorstw..., op. cit., s. 306.

${ }^{45}$ IDW Standard: Principles for the Performance of Business Valuations..., op. cit., s. 29-34.
} 


\section{PODSUMOWANIE}

Przeanalizowane standardy wyceny wykazują liczne podobieństwa w zakresie podejść i metod wyceny przedsiębiorstw. Większość standardów wyceny przedsiębiorstw wyróżnia trzy podejścia do wyceny: dochodowe, majątkowe i porównawcze/rynkowe. Wyjątkiem są tu standardy kanadyjskie, które w miejsce podejścia majątkowego wymieniają podejście kosztowe, natomiast standardy AICPA traktują podejście kosztowe jako alternatywne w określonych sytuacjach do podejścia majątkowego. Standardy amerykańskie IBA, NACVA, ASA oraz standard chiński i międzynarodowy IACVA nie specyfikują metod wyceny. Standardy AICPA, ASA, międzynarodowe IVSC oraz standard niemiecki i polski odnoszą się do szczegółów metodycznych w ramach poszczególnych podejść i wybranych metod wyceny. Standard niemiecki w przeciwieństwie do pozostałych metod uznaje, że wartość przedsiębiorstwa właściwie odzwierciedlają jedynie metody $w$ ramach podejścia dochodowego. Podejście porównawcze dla standardu niemieckiego pełni jedynie funkcję pomocniczą lub kontrolną, a podejście majątkowe znajduje zastosowanie jedynie w sytuacjach innych niż kontynuacja działalności. Standardy amerykańskie AICPA, ASA i międzynarodowe IVSC jako jedyne regulują zasady stosowania reguły kciuka. Standardy ASA i międzynarodowe IVSC wskazują w jakich przypadkach podejście majątkowe znajduje zastosowanie przy założeniu kontynuacji działalności, przy czym standardy ASA zastrzegają, że podejście majątkowe nie może być jedynym podejściem wykorzystanym w wycenie. Pozostałe analizowane standardy wyceny przedsiębiorstw nie zawierają żadnych wskazówek metodycznych w zakresie podejść i metod wyceny.

\section{BIBLIOGRAFIA}

APES 225 Valuation Services, Accounting Professional and Ethical Standards Board, July 2008. ASA Business Valuation Standards, American Society of Appraisers, 2009.

Business Appraisal Standards, The Institute of Business Appraisers, 2008.

IDW Standard: Principles for the Performance of Business Valuations (IDW S 1 Version 2008), IDW Verlag GmbH, Institut der Wirschaftsprüfer in Deutschland, Düsseldorf 2009.

Independent Business Valuation Engagements, Advisory Engagement Standard 2, Council of the Institute of Chartered Accountants of New Zealand, 06/2003.

International Glossary of Business Valuation Terms, w Valuation of a Business, Business Ownership Interest, Security, or Intangible Asset, Statement on Standards for Valuation Services Issued by the AICPA Consulting Services Executive Committee, American Institute of Certified Public Accountants, Inc., New York 2007.

International Valuation Standards. International Valuation Guidance Note No. 6. Business Valuation, The International Valuation Standards Committee, 2007.

Nota Interpretacyjna NI 5, Wycena przedsiębiorstw, Powszechne Krajowe Zasady Wyceny (PKZW), XIX Krajowa Konferencja Rzeczoznawców Majątkowych, Udział rzeczoznawców 
majątkowych w wycenie przedsiębiorstw. Zasady dobrej praktyki zawodowej, Polska Federacja Stowarzyszeń Rzeczoznawców Majątkowych, Kielce 2010.

Professional Standards, International Association of Consultants, Valuators, and Analysts (IACVA), June 1, 2011.

Professional Standards, National Association of Certified Valuation Analysts, May 31, 2002.

Standard no 110-530, The Canadian Institute of Chartered Business Valuators, June 2009.

The Hong Kong Business Valuation Forum. Business Valuation Standards, The Hong Kong Business Valuation Forum, November 2005.

Valuation of a Business, Business Ownership Interest, Security, or Intangible Asset. Statement on Standards for Valuation Services, American Institute of Certified Public Accountants, New York June 2007.

Piotr Szymański

\section{VALUATION APPROACHES AND METHODS IN BUSINESS VALUATION STANDARDS}

This paper tries to analyze whether and to what extent business valuation standards regulate valuation approaches and methods. The paper includes research carried out on 12 business valuation standards (four American standards, Canadian, Australian, New Zealand, Chinese Hong Kong, German, Polish and two international standards) in order to show differences and similarities in regulations. The research shows that some business valuation standards interfere very deeply in the scope of valuation approaches and methods. method.

Key words: business valuation, business valuation standards, valuation approach, valuation 